\title{
INTERVIEW
}

\section{Views from the Secretary-General's Office: An oral history of the United Nations}

\section{Interview with Kofi Annan}

Romuald Sciora

Program in International Relations, New York University, New York, USA.

E-mail: sciora.r@fagf.info

International Politics Reviews (2018) 6, 88-92. https://doi.org/10.1057/s41312-018-0053-9;

published online 13 June 2018

\begin{abstract}
"The vocation of the United Nations is to serve the interests of the world's populations"

Kofi Annan was born on April 8, 1938, in Kumasi, Ghana. He was the seventh Secretary-General of the United Nations Organization and the first to come from the ranks of UN personnel. He began his first mandate in January 1997 and was re-elected in 2001 for a second term in office, which lasted until the end of December 2006. During his career at the UN, Kofi Annan held the office of under Secretary-General (March 1992-February 1993), then deputy Secretary-General for peacekeeping operations (March 1993-December 1996). In April 2000, he published the Millennium Report which became the inspiration for the Millennium Declaration adopted by the heads of state and government at the Millennium Summit, which was held in New York in September 2000. Kofi Annan was awarded the Nobel Peace Prize in December 2001.
\end{abstract}

Romuald Sciora: What was your conception of the role of the Secretary-General of the United Nations before you were elected to that position? Did your conception change during the course of your two mandates?

Kofi Annan: When I was elected, most people, and I was the first among them, had the tendency to be interested solely in the political aspect of the position with respect to the role of mediation and the good offices of the SecretaryGeneral. There were, however, other areas where the organization, although it was very actively involved in the humanitarian sector, was not as involved as it ought to have been and where it suffered from a real lack of communication; I am particularly referring to actions concerning economic development, the battle against disease and, more generally, our relations with the public. It is important that the Secretary-General contribute to reinforcing public confidence in the organization. 
R. S.: From the very beginning of your term in office, you made it your primary priority to revitalize the United Nations through a thorough program of reform and of rebuilding public confidence in the organization through "making the United Nations more responsive to the people it served." What drove you to undertake this reform and to restore the image of the organization? What was your approach?

K. A.: In a world that is undergoing profound changes, the UN must adapt in order to be able to provide effective solutions to the planet's problems. It seemed to me that it was necessary not only to institute structural and administrative reforms, but also to evaluate our goals and objectives in order to reorient some of our missions toward further strengthening the cohesion of the UN system. Aside from the New York headquarters and the five regional economic missions, the UN has established numerous programs and foundations like UNICEF, the UN.

Development Agency and the World Food Program. I believe that we have succeeded in improving the interaction between these various programs.

I also tried to stress the purpose of the United Nations, which is to serve the interests of the people. We should not be an inaccessible bureaucracy hidden away in our glass house. Quite the contrary, we must reach out to the people in order to understand more fully their needs and also that they, in turn, will understand what we as an organization can accomplish. This required that we work together in a partnership not only with governments, but also with civil society, non-governmental organizations, the private sector, universities, foundations, etc.

Today we are at the head of a very tightly knit network within which we combine our strengths in working toward a common goal.

\section{R. S.: After nearly a decade at the head of the Secretariat, do you feel that you have achieved your goals of reforming the organization?}

K. A.: We have made a lot of progress, but obviously reform remains an ongoing process. We must continually strive toward excellence. Beside administrative reforms, I am happy to say that we have been better able to convince the Member States to accept their responsibility, especially in the area of protecting their citizens from human rights abuses. When governments cannot or will not assume their responsibility, it is up to the international community to do so, through the Security Council. I feel that any reform of the United Nations should be based on the principle that without development, there is no security, and vice versa, through respecting human rights and the principle of freedom, in keeping with the Charter. I think I can say that there has been a consensus that has developed over the past several years among the Member States, with respect to the Millennium Goals, to agree that there is a link between the struggle against poverty, security, development and human rights.

\section{R. S.: In your opinion, what have been the organization's most important successes since you became Secretary-General?}

K. A.: I would say the Millennium Goals for Development, which were adopted in 2000 and received remarkably well by all the Member States and also by the international institutions, most notably The World Bank and the International Monetary Fund, and the NGOs. As far as I know, it is the first time that we have come together in such a united front to eliminate poverty. It is a great success.

We established eight goals to be met before 2015; the principle goals are to reduce by half the number of people who live in extreme poverty, to ensure access to clean drinking water and to education. Did you know that currents estimates put the number of children, mostly young girls, who don't go to school at between 100 and 150 million? It is, after all, a right. The Millennium Goals also encourage governments to take measures to protect the environment.

\section{R. S.: And the greatest failures?}

K. A.: Iraq, of course...I had hoped that the United Nations would be able to manage that crisis in such a way that war could be avoided, through the work of our inspectors who were assigned the task of disarming Iraq without resorting to violence. That was not the case, the bombs have had their say and this war has opened up deep divisions between the Member States. These divisions are slowly healing, but the Iraq affaire undoubtedly disrupted the harmony that reigned previously between the Member States.

The other failure was the fact that we were unable to come to the aide of all those who were in desperate straights. After the tragedy of Rwanda, everyone said, "Never again." However, history is repeating itself today in Darfur, where we have been very slow to intervene.

\section{R. S.: Can you describe your reaction to the news} that Sergio Vieira de Mello and members of his team in Baghdad had been killed in August 2003?

K. A.: I had known Sergio for more than twenty years. He was not just a colleague; he was also and especially a friend. I learned of his death while I was in Europe, where I 
was spending my vacation with my wife. We were in Scandinavia. I had spoken to Sergio on the 18 August and I had said: "Sergio, I'm in Europe. Before I return to New York, I would like you to come and meet with me somewhere in Europe. I'll call you tomorrow to let you know when and where we can meet." He was in a good mood. I was very happy to speak to him, and he took the opportunity to remind me that his mission in Iraq was coming to an end: "Mister Secretary-General, don't forget that you had agreed that I could take six weeks of vacation to go visit my mother in Brazil." I told him that he certainly deserved a vacation and that, of course, he could take it. It was a very pleasant conversation. The next day, he was dead. It was very painful for me; his death had a profound impact on me, both professionally and personally. As Secretary-General, and in keeping with the mandate from the Security Council, I had sent colleagues and friends to Iraq, and they had been killed...I had sent them to pay with their lives for this war that I had never supported personally. It was very difficult for me.

\section{R. S.: You have personally been very much involved in the struggle against AIDS. What kind of contribution can the UN make in this effort, particularly in Africa?}

K. A.: The pandemic of AIDS is one of the greatest crises threatening humanity, or at least our generation. In USA and in Europe, there are the means to treat the disease for most people. But in Africa, contracting AIDS is the same as a death sentence. The illness is not present just in Africa, but that is the part of the world where it inflicts the most damage. On the African continent, AIDS paralyzes governmental action; more importantly, it negates the future. The virus hits teachers, nurses, civil servants, agriculture workers, and it leaves millions of orphans in its wake. It is not uncommon to see children of just twelve years of age assuming the responsibility of parents and taking care of their younger brothers and sisters. There are countries in Africa today where the life expectancy is only 37 or 38 years of age and that figure is constantly declining. Without bold measures to put an end to this epidemic, we will face very serious problems in Africa. But AIDS is also spreading quickly in Asia and Eastern Europe.

One often speaks of weapons of mass destruction that are capable of killing thousands of people all at once; but AIDS destroys the lives of millions of people. How much longer can we continue to tell a patient infected with the AIDS virus in a hospital in Africa that he is going to die, whereas he knows that there are medications that can save him? The wealthy have the choice to live, but not him. It is urgent that a world-wide foundation against AIDS, malaria and tuberculosis be established to help their victims and to develop means of prevention. We must promote the use of condoms, intensify vaccination campaigns and assure that pregnant women are given the necessary medications. Nevirapine pills can prevent the transmission of the virus from mother to child during pregnancy, which is the most cruel form of contracting the disease. Innocent beings are born into the world infected with the scourge of AIDS while at the same time we are capable of preventing it.

\section{R. S.: What was the reaction in the House of Glass to the tragedy of September 11, 2001? And your own personal reaction?}

K. A.: I was shocked. I remember that at first we were getting confusing and contradictory reports. At first we were told of a helicopter accident or that a small private plane had crashed into the World Trade Center. But when I turned on the TV, I realized that it wasn't a small plane and that there was not just one, but two planes involved. It was unbelievable; it was even worse than the very worst disaster films.

The Member States of the United Nations quickly joined together and expressed their solidarity with the victims of the attack and with the US people. Everyone at the UN agrees that September 11 has changed USA; but when I talk to my US friends, they go even further in stating that September 11 has changed the world. This difference in point of view goes a long way in helping us to understand the geopolitical consequences of these attacks.

\section{R. S.: What was your relationship with President Clinton like and what kind of a relationship do you have today with his successor, George W. Bush?}

K. A.: I had a very good relationship with President Clinton, whom I consider to be a friend. We are still in close contact and are working together on the tsunami project. I also have a good relationship with President Bush, who is a charming man. We worked well together, in spite of some disagreements, especially over Iraq. He fully understood my position and one day he even said to me: "Kofi, I understand. You have to do what you have to do and I must do what I have to do." I'm not sure that everyone understands it, but I can assure you that we actually have a very good relationship. We were recently able to discuss all of that during the G8 summit at Gleneagles.

President Bush was one of the first to help us in the fight against AIDS. The USA has contributed in the neighborhood of 200 million dollars to the foundation that I wanted to establish for AIDS, malaria and tuberculosis. President Bush has set things in motion to such an extent that other 
governments are now on board. Today, we are able to disperse billions of dollars through the foundation.

\section{R. S.: Who are the personalities who have impressed you the most and why?}

K. A.: You're trying to lay a trap for me! Everyone I am not going to mention is going to ask me why they weren't on my list! In my role as Secretary-General, I have met many outstanding people. I would say that I have worked with some remarkable and impressive heads of state who have accomplished a lot, not only for their countries, but also on a global scale. I am particularly thinking of my friend, Nelson Mandela, who transcended his own nation and who has demonstrated to all of us the world over his exceptional capacity for compassion, forgiveness and reconciliation. After all those years spent in prison, who would have thought that it would be possible for him to be able to work together with the whites and to be elected as a president without any bitterness, the president of all South Africans, black and white? In my opinion, he has been a marvelous inspiration in this divided world in which we live.

\section{R. S.: A part of world opinion criticizes the UN for being a pawn of the USA. In the USA, on the other hand, there are numerous voices who feel that the United Nations is only concerned with the problems of the developing world. How do you explain these contradictory attitudes?}

K. A.: The headquarters of the UN are located in the USA, a very powerful country, a true super power. Because of the political influence the USA wields, it plays a very important role within the United Nations. But one must not loose sight of the fact that the UN is above all an organization of sovereign states, and that the USA is only one out of one hundred and ninety countries. They often have to plead their case before the other nations; that was particularly true in the case of the situation in Iraq, where the USA failed to convince certain other members of the Security Council to support the war in Iraq.

As far as the reverse perception that the UN is mostly concerned with the interests of the Third-World, we should remember that many of these countries didn't exist when the United Nations was formed. Be they big, small, rich or poor, each Member State has one vote, contrary to what is the case at the World Bank and the World Monetary Fund where the number of votes allotted to each member country is determined by the size of its contribution. There are voices that are critical of the fact that the USA, which contributes roughly $22 \%$ of the budget of the UN, has but one vote, the same as those countries that contribute just $0,1 \%$ of that same budget. It can happen that groups of countries join forces in opposing the USA, but generally speaking, I believe that I can say that the Member States are able to work together intelligently.

When one walks through the hallways of the United Nations, one hears almost all of the languages in the world. All cultures and all religions are represented, and that fact is not an obstacle in the decision-making process. It is, of course, true that negotiations are often long, but that is part of the process. It's like a scientist who is working on an invention. He starts off by conducting an experiment, but he must perhaps conduct as many as a hundred before he succeeds. Nevertheless, the ninety-nine experiments that were performed beforehand cannot be considered to be a waste of time. That is how we operate at the United Nations, in the service of a more just world. In spite of all the differences, things work out in one way or the other.

\section{R. S.: What role should the United Nations and its Secretary-General play in the new world order that is emerging?}

K. A.: Everyone is now aware that we live in a global village and that the world is more than ever before interconnected. Just look at what happened with the SARS [Severe Acute Respiratory Syndrome] epidemic: it started in Asia and several hours later was detected in Canada. We have also seen what happened with terrorism and the need to work together to contain these global threats.

Faced with such challenges, the United Nations represents a guarantee of efficiency, because it can bring together all the governments of the world so they can join forces to combat these problems they all have in common. These are matters that no single country, no matter how powerful, can deal with alone. We have the responsibility to establish international norms that will provide the framework for governmental actions.

\section{R. S.: What is your own evaluation of your career in the service of the United Nations?}

K. A.: I think that, in a very modest way and with the approval of all the Member States, I have tried to strengthen the organization through consolidating its various components. From an intellectual and conceptual point of view, I have tried to focus my actions in a direction that I feel is the best one for today's world. We haven't just concentrated on political matters or on security. We have also worked quite a bit on questions of development and on social issues, because there are often underlying economic reasons behind the conflicts that break out. 
There will never be peace in the world as long as extreme poverty continues to co-exist alongside enormous wealth. This inequality between and within countries is becoming increasingly unacceptable. We must permit people to live in dignity and be receptive to their concerns. We must more than ever continue to exert pressure to assure that human rights are respected.

The only way to reach the goals that we have set for ourselves is to work together with the greatest number of partners possible. I am very happy about the support we have received these past years from NGOs, the private sector, universities and foundations that are working with us. The Ted Turner Foundation has contributed a billion dollars to our social and humanitarian program. Bill Gates has also donated more than a billion dollars to projects related to health.

\section{R. S.: How would you prefer that History remember you and your efforts?}

K. A.: I would be satisfied if, on my departure from the organization, one acknowledges that the United Nations functions a bit better than it did when I arrived.

Interview filmed in New York in August 2005 